\title{
Parisian Street Names \\ in George Du Maurier's Trilby
}

\section{Elizabeth A. Hait}

In his second and most famous novel, Trilby, George Du Maurier, who was bilingual in French and English, created imaginary street names for the Parisian setting. These names, when translated into English, give insight into or reflect the personalities of the characters who inhabit or frequent the streets.

In 1894, at the age of sixty, George Du Maurier published his second and most famous novel, Trilby. This novel, written in English like his other two, illustrates the intermingling in Du Maurier of the French and English cultures and of the two languages. Henry James, a personal friend of Du Maurier, remarked in the September 1897 edition of Harper's New Monthly Magazine,

"I have never known, I think - and in these days we know many - an international mixture less susceptible of analysis save on some basis of saying...that all impulse, in him, was of one race, and all reflection of another." (Ormond 403-404)

Du Maurier was born in Paris in 1834, the elder son of a French father and an English mother, and before he had reached the age of twenty-two, he had lived on both sides of the English Channel. In 1856, Du Maurier journeyed from England to Paris to begin his study of art, and he remained in Paris for one year. Much of the first half of Trilby is based upon his experiences and observations during that year.

Names 42.1 (March 1994):19-25

ISSN:0027-7738

() 1994 by The American Name Society 


\section{Names 42.1 (March 1994)}

In 1857, having moved to Antwerp to continue his study of painting, Du Maurier lost his sight in one eye and gave up all hope of becoming a serious artist. Back in London in the early 1860s, while he was intent upon establishing himself as a cartoonist for Punch magazine, he wrote a short story based on his experiences as an art student in Paris. In a letter to a friend, Du Maurier stated that "Lamont is there as the wise and facetious Jerry, you as the bullnecked \& sagacious Tim; the street is our Lady of the Bohemians" (Ormond 441). This story, which may be considered an early version of Trilby, was rejected by both Cornhill and Once A Week, and no copy of it has ever been found (Kelly 58). Yet from this remark in a letter to a friend can be seen Du Maurier's interest in street names and their use for an effect.

In Trilby, published some thirty years later, Du Maurier portrays three aspiring young English art students who take a studio in the Latin Quarter of Paris in order to study painting. Little Billee, the main character, is young, polite, rather naive, and the most talented of the three. Taffy and the Laird, the other two, are his true-blue English friends. In the Latin Quarter, these three encounter the beautiful Trilby, a model with whom Little Billee falls in love, and the sinister Svengali, a musician with hypnotic powers. As Du Maurier describes the milieu, he uses his knowledge of the city of Paris and the rich associations that mere names can call up in readers' minds. He sends his three young men to the Rue de Rivoli, to the Place de la Concorde, and to Christmas Eve services at the Madeleine. They walk across the Pont des Arts and the Pont Neuf, and they visit Notre Dame Cathedral and even the Morgue on the Ile de la Cité. All of these names add color to this novel set in Du Maurier's beloved Paris.

And yet not all of the street names used in the novel appear on a current map of Paris. During his year there (1856) Du Maurier would have witnessed major changes in the Parisian cityscape as Napoleon III and Baron Georges Eugène Haussmann "cleared out disgraceful slums on both banks and on the Cite" (Pinkney 58) and began or continued the construction of wide boulevards. In fact, towards the end of the novel, when Taffy and the Laird return to Paris after an absence of five years and attend a performance at a music hall, the narrator refers to the changes in the city as follows: 
Just at this period of the Second Empire there was a mania for demolition and remolition (if there is such a word), and I have no doubt my Parisian readers would search the Rue St. Honoré for [the music hall] in vain! (313)

These circumstances in Paris may have inspired Du Maurier and justified the freedom he took in giving some of the streets in his novel imaginary French names, for neither his Parisian nor his English readers would have found them on a map of Paris in the 1890 s, when the novel was published, nor would they have found them in a street guide to Paris in the early 1850 s (e.g., The Miniature Guide to Paris and its Environs), before major demolition and construction had begun. So in Trilby, Du Maurier uses his imagination to create new street names, to create a "mixed onomastic [world]: historically averred...places alongside invented names" (Grimaud 30), just as he had apparently planned to do in his first short version of the novel.

Thus, though the names of many of the major streets of Paris have remained the same since the nineteenth century, others have changed names, been widened into avenues, or completely disappeared. Du Maurier capitalizes on these changes in Trilby and often uses an imaginary street address as a comment on the character who lives on that street or frequents it. The studio where the Laird, one of the three Englishmen, lives and where his cohorts, Taffy and Little Billee, along with Trilby, Svengali, and a host of others spend much of their time, is located in the Place St. Anatole des Arts in the Latin Quarter, close enough to the Seine River to enable them to see the Ile de la Cité from their window. This name, Place St. Anatole des Arts, cannot be found on a current map of Paris; however, in the immediate vicinity of the place described, just west of the Place St. Michel, is the Place St. André des Arts. It is not clear exactly why Du Maurier changed the André to Anatole in St. Anatole des Arts. Several saints with the name of Anatole, most having a variation in the ending of the name (Anatolia, Anatolius), are listed in The Book of Saints. One of these whose story is similar in some ways to Trilby's is St. Anatolia, who died around A. D. 250. She was a "Roman maiden [who was] denounced with her sister Victoria, by their rejected lovers" (53), as Trilby was at first denounced by Little Billee. 


\section{Names 42.1 (March 1994)}

Her story is also told in The Roman Martyrology, where her sister is not mentioned but where more details of her life are given. Having cured many people and won them to Christ, she was judged and tormented, and finally she was "deliuered from a Serpent that was set vpõ [upon] her" (Keynes 214). Trilby may also be said to have been delivered from a serpent after suffering torments, for she was at last delivered from Svengali, whose real name was Adler, a name bearing a strong resemblance to adder.

From the Place St. André (Anatole) des Arts on the Left Bank near the Pont Neuf, a person could easily see the Ile de la Cite, the Morgue, and the towers of Notre Dame, the view that Du Maurier describes several times in the novel. The name St. André des Arts goes back at least as far as 1802, for Thomas Holcroft, an English writer who visited Paris in that year, uses the name in his journal as an example of the misspelling of street signs in Paris. He writes, "The street, the true name of which is St. André des Arcs, is not only frequently printed but is labelled at the end of it St. André des Arts" (1:187). In a note, Holcroft explains that the original name for the street, which runs into the "place" of the same name, referred to the fact that "men who made bows and arrows formerly inhabited that street" (1: 187, n. $)$ ). By the late 1850s, the time in which the early chapters of Trilby are set, the misspelling had become a more appropriate name for the area than the original because of the large number of artists who lived there.

The addresses of other characters reinforce what Du Maurier said about them. At the beginning of the novel, Svengali lives in "a roomy dilapidated garret,...in the Rue Tire-Liard" (57). According to Le Robert et Collins, one of the meanings of tirer is associated with money: tirer de l'argent de [quelqu'un] means 'to get money out of [somebody]' (663). In fact, the noun tire, when used in the phrase vol à la tire, means 'picking pockets' (663). And liard is the French word for 'farthing' (383). These two words together emphasize Svengali's poverty and are a direct comment on his habit of borrowing money from his friends. Another address that complements, literally, the picture of a character drawn in words and in lines by Du Maurier, who also illustrated the novel, is the name of the street on which Trilby lives - la Rue Pousse-Cailloux. The compound poussecailloux is another term, according to Le Petit Robert, for fantassin 
(1502), which means 'foot soldier' or 'infantryman' (Le Robert et Collins 280). This word is doubly descriptive of Trilby, for the very first description of her in the novel combines both parts of the definition, foot and soldier:

\begin{abstract}
It was the figure of a very tall and fully developed young female, clad in the gray overcoat of a French infantry soldier, continued netherwards by a short striped petticoat, beneath which were visible her bare white ankles and insteps, and slim, straight, rosy heels, clean cut and smooth as the back of a razor; her toes lost themselves in a huge pair of male list slippers, which made her drag her feet as she walked. (15)
\end{abstract}

Thus, the name of the street on which Trilby lives is appropriate to her because of her dress in this scene and because of the emphasis placed on her feet throughout the novel.

The address of the studio where Little Billee studies painting is also suggestive of the activities that go on within. Du Maurier explains that

\begin{abstract}
Carrel's atelier (or painting-school) was in the Rue Notre Dame des Potirons St. Michel, at the end of a large court-yard, where there were many large dirty windows facing north, and each window let the light of heaven into a large dirty studio. (76)
\end{abstract}

Though many Parisian street names are long, this one is especially so, and its three major parts serve as a comment on the action of the novel. First of all, Little Billee is obviously in love with Trilby, and he idealizes her even though he knows that she poses as a model in the nude. He and his English friends respect her as one would respect Notre Dame, the mother of Christ. At the end of the novel, even the minor character Gecko, who, as his name suggests, is small and lizardlike, mentions Trilby's "good smile like the Madonna's" (456). As long as Little Billee does not actually see Trilby posing in the nude, he can continue to idealize her.

The second part of the street name, des Potirons, literally means 'pumpkin[s]' (Le Robert et Collins 509). But potirons is also a homophone for the two words peau and tirons. The word peau literally means 'skin' (476) though it is often used to describe a 


\section{Names 42.1 (March 1994)}

person's complexion. It does not, however, refer only to facial skin, and after 1845, the word acquired the derogatory connotation 'prostituee' (Le Petit Robert 1384). Du Maurier, who was not only bilingual but also well versed in French argot (Whiteley 16), would probably have been aware of this connotation. Tirons, a form of the verb tirer, is appropriately used to indicate the location of a studio, for one of its many meanings is 'to draw' or 'to paint,' as in the phrase se faire tirer le portrait (Le Robert et Collins 663). Together, the two words literally mean 'let us paint skin,' and they imply the painting of nude models that goes on in the studio. Little Billee is not opposed to painting the human body, but because he loves Trilby, he is opposed to her modeling in the nude.

The third component of the street name, St. Michel, is also appropriate to the action that takes place in the studio, for when Little Billee arrives one day, after a short absence, he finds Trilby seated on the pedestal in the studio and posing in the nude for his fellow art students. He finally has to face Trilby's posing in the nude (in the novel they say "in the altogether"), and the force of this reality drives him from the studio. His idealization of Trilby ends, and this revelation, so to speak, casts him out of his paradise, just as the Archangel Michael casts out Adam and Eve in Paradise Lost. These three component parts of the street name, then, comment on the progress of Little Billee's relationship with Trilby and on the impact of the scene at the studio on this progress.

Finally, an imaginary street name reinforces the author's opinion of the British philistines who inhabit Paris. After Little Billee leaves the city, the circle of friends who met at the studio in the Latin Quarter gradually breaks up, and Taffy and the Laird become more and more conservative. Du Maurier writes that, at last, these two

had themselves proposed and seconded for the Cercle Anglais in the Rue Sainte-n'y touche, a circle of British philistines of the very deepest dye; and went to hear divine service on Sunday mornings. (224)

Le Robert et Collins states that de sainte nitouche denotes an 'air hypocritically pious' (602). The author can, in this way, suggest the hypocrisy of these Englishmen without actually calling them hypocrites. Du Maurier thus combines a fascination with the vivid street 
names of Paris with a fluency in French to produce highly suggestive street names for the setting of his most famous novel, Trilby.

\section{McNeese State University}

\section{Works Cited}

Benedictine Monks of St. Augustine's Abbey, Ramsgate, comps. The Book of Saints. 5th ed. New York: Crowell, 1966.

Coghlan, Francis. The Miniature Guide to Paris and its Environs. London: J. Onwhyn, 1853.

Du Maurier, George. Trilby. New York: Harper, 1894.

"Fantassin." Le Robert et Collins Dictionnaire. 1982 ed.

Grimaud, Michel. "Onomastics and the Study of Literature." Yearbook of Comparative and General Literature 38 (1989): 16-35. Holcroft, Thomas. Travels from Hamburg, through Westphalia, Holland, and the Netherlands, to Paris. 2 vols. London: Richard Phillips, 1804.

Kelly, Richard M. George Du Maurier. Boston: Twayne, 1983.

Keynes, George, S.J., trans. The Roman Martyrology. St. Omer:

English College Press, n.d., pp. 214-215.

"Liard." Le Robert et Collins Dictionnaire. 1982 ed.

Ormond, Leonée. George Du Maurier. Pittsburgh: U of Pittsburgh P, 1969.

"Peau." Le Petit Robert Dictionnaire. 1977 ed. . Le Robert et Collins Dictionnaire. 1982 ed.

Pinkney, David H. Napoleon III and the Rebuilding of Paris. Princeton: Princeton UP, 1958.

"Potiron." Le Robert et Collins Dictionnaire. 1982 ed.

"Pousse-cailloux." Le Petit Robert Dictionnaire. 1977 ed.

"Saint." Le Robert et Collins Dictionnaire. 1982 ed.

"Tire." Le Robert et Collins Dictionnaire. 1982 ed.

"Tirer." Le Robert et Collins Dictionnaire. 1982 ed.

Whiteley, Derek Pepys. George Du Maurier: His Life and Work. London: Art and Technics, 1948. 